\title{
International Journal of Animal Research (ISSN:2575-7822)
}

\section{Socio-cultural, Herd Structure and Reproductive Practices of Pastoral Cattle Producers in Adamawa State, Nigeria}

\section{H. KUBKOMAWA', M. S. ADAMU', M. A. OGUNDU' ${ }^{2}$, I. C. OKOLI ${ }^{2}$ and A. B. I. UDEDIBIE ${ }^{2}$}

${ }^{1}$ Department of Animal Production and Health, Federal Polytechnic, Pmb 35, Mubi, Adamawa State, Nigeria; ${ }^{2}$ Department of Animal Science and Technology, Federal University of Technology Owerri, Imo State, Nigeria

\begin{abstract}
The objectives of the study were to investigate the socio-cultural, herd structure and reproductive practices of pastoralist cattle producers in Nigeria. The study was carried out with the aid questionnaires, oral interview and field observations on 300 respondents spread across the three study LGAs. Pastoral cattle production in Adamawa state was predominated by highly experienced $(80-85 \%)$, married $(75-88 \%)$, male $(75-90 \%)$ Fulani $(95-65 \%)$ Muslims $(75-80 \%)$ aged mostly $31-40$ years $(48-55 \%)$ and having limited western education. White Fulani $(50.00 \%)$ was the most common breed in Gombi LGA, while Red Bororo (53.00\%) and Adamawa Gudali (50.00\%) were the most predominant breeds in Mubi North and Jada LGAs respectively. Most of the pastoralist $(40-50 \%)$ maintained herd size of 41 to 50 heads and reared cattle for multiple purposes such as breeding, milk, meat and traction. Farmers practiced uncontrolled breeding, with bull to cow ratio of $1: 10(75.00 \%$ at Mubi north LGA). First mating $(50-60 \%)$ was done between 4 and 5 years, while age at first calving (73-75\%) was mostly $5-7$ years indicating serious reproductive life wastage. Most pastoralists $(55-65 \%)$ use ethno-veterinary practices to enhance cattle reproductive performance. Calving rates $(75-85 \%)$ were more during late rainy season (LRS), while $(90.00 \%)$ depended on natural pastures for feeding their cattle. Cattle graze 21 different species of grasses and 19 legumes during the wet periods, while 12 crop residues, 7 by-products and 10 browse plants were offered during dry periods as supplements. Most of the pastoralists (70.00-90.00\%) depended solely on natural flowing streams and rivers for the supply of water to their cattle. The major production constraints $(43.33 \%)$ identified was diminishing natural resources characterized by shrinking land and vegetal resources. The methods used for reducing poor morphometric effects of lean feed resources were forage conservation as hay, supplementation with tree fodder, migration and splitting of herds. The northern guinea savannah zones, therefore, remains the major environment for cattle production in Nigeria since cattle are highly valued livestock in these zones, where it contributes to the local economy and food security.
\end{abstract}

\section{${ }^{*}$ Correspondence to Author:}

I. H. KUBKOMAWA

Department of Animal Production and Health, Federal Polytechnic, Pmb 35, Mubi, Adamawa State, Nigeria. Email: kubkomawa@ yahoo. com Phone: +2347066996221

How to cite this article:

KUBKOMAWA et al., Socio-cultural, Herd Structure and Reproductive Practices of Pastoral Cattle Producers in Adamawa State, Nigeria. International Journal of Animal Research, 2017; 1:3.

\section{eSciencePublisher 2}

eSciPub LLC, Houston, TX USA. Website: http://escipub.com/ 


\section{INTRODUCTION}

Cattle production and breeding in Nigeria is predominantly controlled by pastoralists who constitute a major socio-economic group in the country (Nweze et al., 2003; Nori and Davies, 2007; Moutari, 2008). These nomads own more than $93 \%$ of the country's estimated 15.3 million cattle population (Umar, 2007; Umar et al., 2008; Tibi, and Aphunu, 2010). Pastoralist livestock industry is therefore, the country's reservoir of animals for slaughter, milk, manure production as well as draft power (RIM, 1992; Parton et al., 2007 and Kubkomawa et al., 2011). The industry also contributed $19 \%$ in 1983 and $1984,10 \%$ in 1998 and $6 \%$ in 2004 and 2005 to agricultural production and 3.2 $4 \%$ to overall GDP of the country (CBN, 1999; Mbanasor, 2000; Ifeanyi and Olayode, 2008).

Cattle are highly valued livestock in northern Nigeria, where it contributes to the local economy and food security. Pastoral production systems play a central role in providing livelihood for rural people, ensuring productive use of marginal lands and contributing to internal trade and earnings (Moutari, 2008). Cattle farming is a sources of employment in the guinea savannah zone of northern Nigeria (RIM, 1992). Cattle are kept mostly for beef, milk, manure and hide as well as for draught power to plough farm lands (Tukur and Maigandi, 1999; Kubkomawa et al., 2011). They also serve other socio-cultural functions such as payment of bride price, transportation of goods and people, prestige and symbol of economic status (Walker and Salt, 2006; Klein et al., 2007).

The pastoralist cattle production system that evolved over the centuries in the zone is based on grazing animals on natural communal pastures and complementary use of fodder and crop residues (Muhammad and Ardo, 2010; Nweze et al., 2012). The system has been defined as an adaptation to the hash and variable physical and environmental conditions of marginal range lands with a view to harnessing the otherwise un-utilizable biomass for production of livestock (Niamir, 1991). There is therefore, a transhumance or seasonal cyclic movement of animals and farming families in synchrony to the rain fall regimes that drives biomass availability (Moran, 2006; Okoli and Kalla, 2008). It is however constrained by threats of animal diseases; insecurity, conflict and increasing shortages of forage and water resources for livestock (Muhammad and Ardo, 2010). Pastoralist livestock management is therefore, becoming increasingly difficult in northern Nigeria due to lack of access to enough land in the wake of rapid population growth and agricultural expansion which result in competitive demand for land resources (Nori and Davies, 2007). The current land use pattern and natural resource development and conservation in Nigeria show that pastoralism is at cross-roads with uncertain future (Okoli and Kalla, 2008; Muhammad and Ardo, 2010). Livestock development and empowerment of pastoralists is plagued by a number of problems which may include, among many others, diminishing land space for grazing and stock movement; deterioration of existing range lands with low biomass yields; scarcity of water; poor carrying capacities of available land; concentration of endemic diseases and parasites; low literacy rates and physical isolation of pastoralists; environmental constraints; absence of functional extension services; distorted agricultural development policies as well as an enduring disconnect between government and aspirations of the pastoralists (Okoli and Kalla, 2008; Muhammad and Ardo, 2010).

To the south of this pastoralist zone is the guinea savannah zone that has more abundant rain fall, biomass resources and permanent water sources. However, this and the rest of the rain forest zones further south are notoriously infested with tsetse fly the vector of trypansomiasis and other humidity related diseases and have therefore prevented the sustenance of pastoralist cattle production for ages (Ikede and Taiwo, 1985; Anosike et al., 2003). These southern zones are home to major crop production activities in the country. 
Recent prolonged droughts, resulting in the carrying capacity of available land is critical shortage of forage and water resources, more efficient control of tsetse fly down south, the wide spread availability of veterinary medicines and the increasing use of crossbred cattle have led to increased migration of the pastoralists and their animals into the guinea savannah and forest zones of Nigeria (Bassett and Turner, 2006). In addition, changes in the political economy of regional livestock markets and ownership have contributed to movements of pastoralists to the south even though they are faced with conflicts of various degrees with indigenous crop producers (Blench, 2010; Nyong, 2010). Thus, the humid tropical rain forest zone of southern Nigeria has become a haven for some pastoralists and their livestock (Blench, 1994; Okoli et al., 2012). Frequent conflicts with crop farmers threatens pastoral access to shared material resources, thus, impacting on the sustainability of pastoralism in the forest zones (Tonah, 2006; Ofuoku and Isife, 2009; Okoli et al., 2012). Current approaches of preventing these conflicts show that controlling reproduction of animals within

(Okoli et al., 2012). The objectives of the study were to investigate the socio-cultural characteristics of the key stake holders, management and the reproductive characteristics of pastoral cattle in Adamawa State, the guinea savannah zone of NorthEastern Nigeria.

\section{MATERIALS AND METHODS \\ The Study Area}

Adamawa State is located at the area where the River Benue enters Nigeria from Cameroon Republic and is one of the six states in the North-East geopolitical zone of Nigeria. It lies between latitudes $7^{\circ}$ and $11^{\circ}$ North of the Equator and between longitudes $11^{\circ}$ and $14^{\circ}$ East of the Greenwich Meridian (Mohammed,1999). It shares an international boundary with the Republic of Cameroon to the East and interstate boundaries with Borno to the North, Gombe to the North-West and Taraba to the West and South (Adebayo, 1999; ASMLS, 2010a; ASMLS, 2010b), as presented in Figure I.

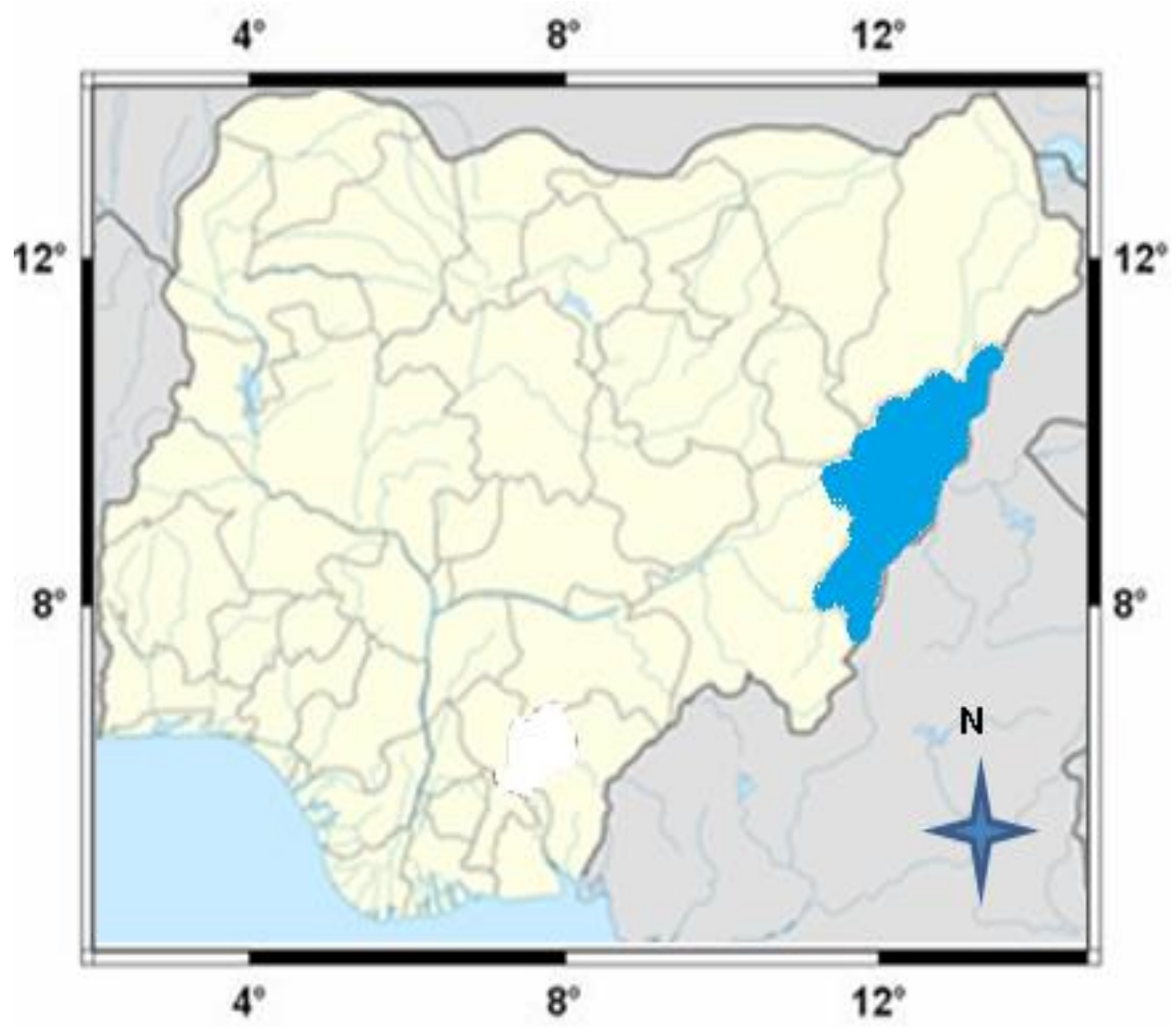

Figure I: Map of Nigeria showing Adamawa state, the study area in blue 


\section{Study design}

Three Local Government Areas, one from each of the three senatorial districts in the State were chosen for the study. The Local Government Areas were purposively selected to cut across the State which represents the pastoral zones with higher number of cattle producers in the State (Adebayo, 1999). The study areas include Mubi North (Northern Senatorial Zone), Gombi (Central Senatorial Zone) and Jada (Southern
Senatorial Zone) as shown in Figure II. Ten communities/pastoral camps were randomly selected in each of the study area and one hundred (100) livestock farms were visited in each study area for interviews, direct observation and data collection across early rainy season (ERS), late rainy season (LRS), early dry season (EDS) and late dry season (LDS), respectively.

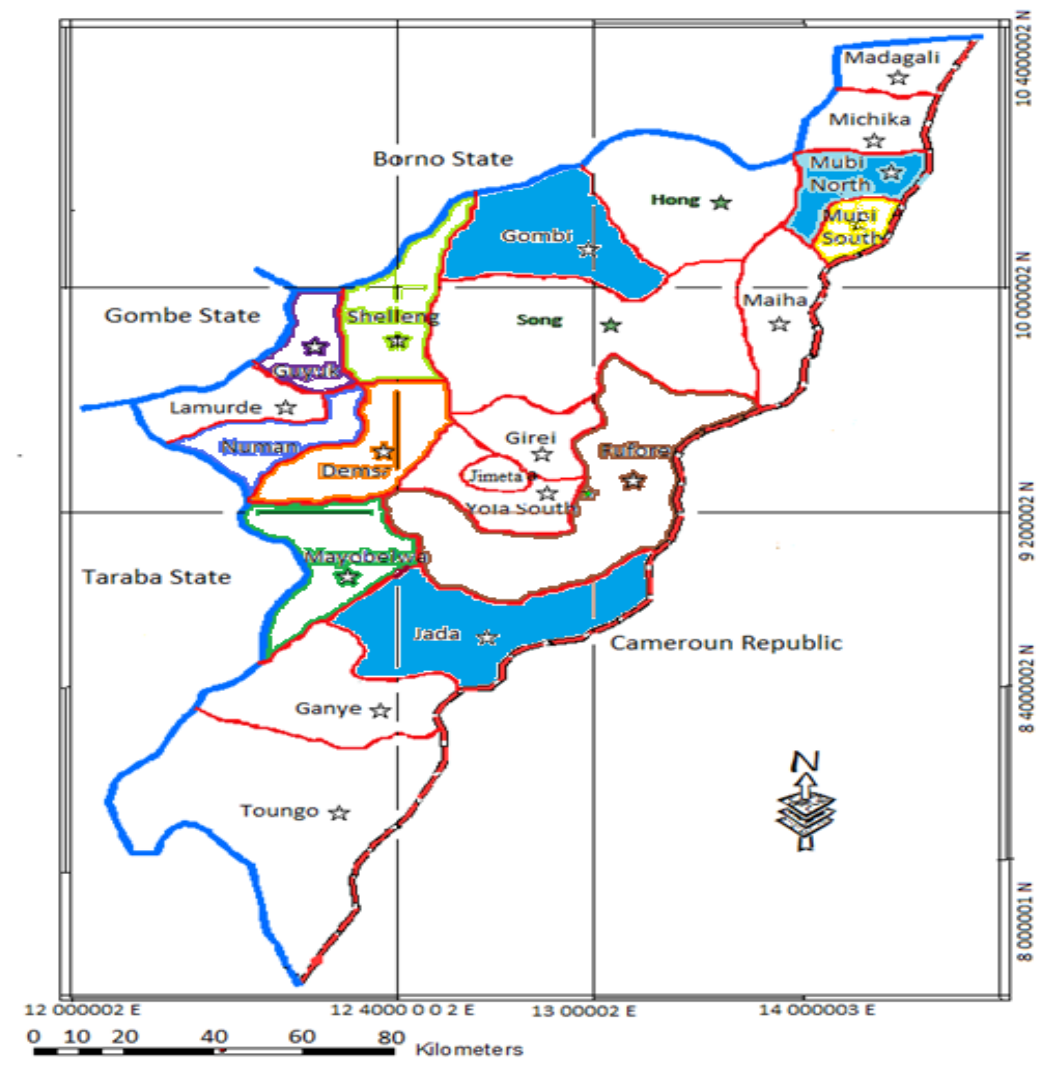

Figure II: Map of Adamawa state showing the three study LGAs in blue

\section{Data Collection}

The data collection instruments include, short questionnaires, oral interviews and field observations. Structured questionnaires were developed in English language and distributed and where a farmer does not understand English, Hausa and Fulfulde languages were used.

\section{Selection of Respondents}

Random selections of respondents were carried out after preliminary survey and ownership of 20 animals ( 15 females and 5 males) were legible for inclusion in this study. Ten communities or pastoral camps were randomly selected at each of the study sites.
Ten farms were randomly sampled from each community making the total of 100 livestock farms visited in each study area for interviews, direct observations and data collection. This was done across four seasons namely early rainy season (ERS), late rainy season (LRS), early dry season (EDS) and late dry season (LDS).

\section{Characterization of Production Components} of Pastoral Cattle

Four breeds of cattle already identified in herds were used for the study. These include White Fulani (Bunaji), Red Bororo (Rahaji), Sokoto Gudali (Bokoloji) and Adamawa Gudali. Ten males and ten females per breed making a total 
of 80 animals in each study area were investigated across the four seasons. The ages of the experimental animals range between 2 and 10 years old.

\section{(a). Socio-cultural characteristics of} livestock producers: Socio-cultural status of cattle producers such as sex, age, educational qualification, marital status, tribal and religious distribution, years of experience were determined by questionnaires, direct field observations and interviews on herd basis.

(b). Management characteristics: Cattle breeds were determined with the aid of farmers; observable peculiar breed distinguishing characteristics were documented. Herd size and purpose of production were determined by questionnaires and interviewing the cattle producers on herd basis.

(c). Reproduction practices: Breeding system, mating method, bull to cow ratio, age at first service, age at first calving, calving interval, calving rate per cow before culling were determined by questionnaires, direct field observation and interviewing of the cattle producers on herd basis.

Seasonal cattle reproductive variation and reproductive enhancement practice were determined by questionnaires, direct field observation and interviewing of the cattle producers on herd basis. Veterinary, ethnoveterinary practices and ethno-veterinary plants were identified. Parts of plants used and how they are prepared were determined. The disease and parasitic conditions cured and the people who use the ethno-veterinary medicines were also determined.

Data Analysis
All the data generated in this study were subjected to descriptive statistics such as tables, frequencies and percentages.

\section{RESULTS AND DISCUSSION}

\section{Socio-Cultural Characteristics of Cattle} Producers in Adamawa State

Table 1 highlighted the socio-cultural characteristics of cattle producers in the guinea savannah zone of Adamawa State, Nigeria. Livestock systems diagnostic research employed in this study involves detailed investigation of all the stake holders, animals and the production environment (Roeleveld and van den Broek, 1996) of the guinea savannah zone in Adamawa State. As a component of this systems research, survey of the socio cultural characteristics of livestock producers is necessary because cattle production in Nigeria is predominantly controlled by pastoralists (Umar et al., 2008). Cattle production in Nigeria seems to have entered a transition period that has resulted in extensive movement of animals to new production zones (Blench, 1994; Okoli et al., 2012). Thus, redistribution of cattle ownership (Basset and Turnner, 2006), semi sedentarization of nomadic pastoralists (Cisse, 1980; Anosike et al., 2003) and new diseases and production dynamics (Anosike et al., 2003; Okoli et al., 2012) are being experienced. Therefore, since pastoral areas are not isolated from national and international political and socio-economic dynamics captured in the planning of development programmes, the interactions between the pastoral and broader sectors must be taken into account to achieve holistic results (Bonfiglioli, 1992; Johnson, 1993).

Table 1 Socio-Cultural Characteristics of Cattle Producers in Adamawa State

\begin{tabular}{lcccccc}
\hline Parameters & \multicolumn{2}{c}{ Mubi North } & \multicolumn{2}{c}{ Gombi } & \multicolumn{2}{c}{ Jada } \\
& Freq & \% & Freq & \% & Freq & \% \\
\hline (a) Sex & & & & & & \\
Male & 90 & 90 & 75 & 75 & 87 & 87 \\
Female & 10 & 10 & 25 & 25 & 13 & 13
\end{tabular}

(b) Marital

Status

Married 


\begin{tabular}{lllllll}
\hline $\begin{array}{l}\text { Divorced } \\
\text { (c) Age (Years) }\end{array}$ & 5 & 5 & 5 & 5 & 2 & 2 \\
$10-20$ & 10 & 10 & 15 & 15 & 10 & 10 \\
$21-30$ & 15 & 15 & 15 & 15 & 30 & 30 \\
$31-40$ & 55 & 55 & 50 & 50 & 48 & 48 \\
$41-$ above & 20 & 20 & 20 & 20 & 12 & 12 \\
(d) Qualification & & & & & & \\
W/Education & 20 & 20 & 30 & 30 & 40 & 40 \\
Nomadic/Arabic & 80 & 80 & 70 & 70 & 60 & 60 \\
(e) Experience & & & & & & \\
$5-10$ & 5 & 5 & 10 & 10 & 5 & 5 \\
$11-16$ & 15 & 15 & 10 & 10 & 10 & 10 \\
$17-22$ & 40 & 40 & 40 & 40 & 40 & 40 \\
22- above & 40 & 40 & 40 & 40 & 45 & 45 \\
(f) Tribe & & & & & & \\
Fulani & 70 & 70 & 65 & 65 & 95 & 95 \\
Hausa & 20 & 20 & 20 & 20 & 2 & 2 \\
Others & 10 & 10 & 15 & 15 & 3 & 3 \\
& & & & & & \\
(g) Religion & & & & & & \\
Islam & 75 & 75 & 50 & 50 & 80 & 80 \\
Christianity & 20 & 20 & 20 & 20 & 10 & 10 \\
Traditional & 5 & 5 & 30 & 30 & 10 & 10 \\
\hline
\end{tabular}

(a) Sex distribution of cattle producers in Adamawa State

Table 1a showed that, majority of cattle producers were male, with Mubi North LG recording the highest $(90.00 \%)$ followed by Jada $(87.00 \%)$ and Gombi $(75.00 \%)$. It was also observed that, men had the highest percentage of livestock holdings because they are the bread winners, having reservoir of wealth and taking the responsibility of managing herds to sustain the family's livelihood. However, women and children although relegated to the background, also, control portions of the livestock holdings to support the family. These findings corroborate that of Okoli et al. (2012) who reported 100\% ownership of pastoralist cattle by men in the humid rain forest of Imo State, Nigeria. Michael et al. (1991), had earlier reported that, the management of herds rest on the men, but children and women, in their capacity as apprentices, also contribute to the family laborforce. Similarly, Adisa and Badmos (2009), in a study of the socio-economics of pastoral livelihood among cattle herdsmen in Kwara State, Nigeria, reported that, cattle herding is entirely a male dominated business. Iro (1994) reported that, cattle belong to individual family members and are usually herded together, with

male family members assuming automatic rights to all cattle, making it difficult to determine cattle ownership by female family members. Swinton (1987) however, reported that, women own most of the small ruminants and all of the poultry.

Informal discussions during the present study revealed that, men who ensure the corporate existence of the family, are the primary household providers and protect the animals from carnivores and theft. They, also, take animals to long-distance pasture lands, find fodder, dig wells, and make weapons such as guns, knives, swords, herding sticks, bows and arrows. The adult males also identify and locate grazing-sites, construct the tents, fences and perform soil and water tests to ensure good hygiene, security and safety.

(b) Marital status of cattle producers in Adamawa State, Nigeria

Table $1 \mathrm{~b}$ showed that, most of the cattle rearers at the study locations were married as 
represented by $88.00,85.00$ and $75.00 \%$ for Jada, Gombi and Mubi North Local Government Areas, respectively. It was observed that, early marriage is part of the norms and values in the culture of Fulani Hausa pastoralists, which allows the setting up of family early in life to preserve family lineage through procreation. The few pastoralists that were found still single were confirmed to be under - aged not because they refused to marry. Some of them were still serving their masters as herdsmen and having their own share of holdings in the herds and are longing to get married as soon as the time is ripe. Another major reason of early marriages is that, women assist in taking care of calves, children and hawking milk to provide additional income to support the household in terms of purchase of grains and other valuables. The men are forbidden to enter the kitchen and find it difficult to eat in public eateries, as such, it is necessary to marry on time. These results also agree with that of Adisa and Badmos (2009), who reported that, $87.5 \%$ of pastoralists surveyed in Kwara State were married.

(c) Age distribution of cattle producers in Adamawa State

Table 1c showed that, most of the pastoralists were aged between 31 and 40 years, with Mubi North, Gombi and Jada Local Government Areas recording 55.00, 50.00 and $48.00 \%$, respectively. Youths are therefore, the most engaged in cattle production business compared to elderly people. This is because, as men get older and advanced in age, they try to share their inheritance among their children to prevent them from fighting over their wealth after their death. Elderly men and women keep only few cattle for the sake of continual daily supply of milk for family food. This also has to be under the care of hired herdsmen in addition to family labour. These findings agree with Okoli et al. (2012), who reported 45\% ownership of pastoralist cattle by youths within the age groups of 31 and 40 years in the humid rain forest of Imo State, Nigeria. Adisa and Badmos (2009), also, reported modal age herders to range from 21 - 35 years, accounting for $37.5 \%$. This may be due to the possibility that, youths are more able to withstand the rigours of transhumance associated with pastoral cattle herding.

\section{(d) Educational qualifications of cattle producers in Adamawa State}

Table 1d revealed that, $80.00,70.00$ and $60.00 \%$ of the cattle producers had only Nomadic/Arabic education, while 20.00, 30.00 and $40.00 \%$ were privileged to have Western education in addition to Nomadic/ Arabic education in Mubi North, Gombi and Jada Local Government Areas, respectively. It was observed that, the low level of conventional Western education was because, most of the cattle producers, especially the Fulani pastoralists are always on the move. There is therefore, a general belief that western education is a waste of time and resources since it is not a needed skill in cattle rearing. The Fulani also believe that, Western education encourages corruption and laziness with no guaranteed future as against the pastoralist world view and values. These results are again in agreement with the report of Okoli et al. (2012) that, $86.4 \%$ of Fulani pastoralists have Arabic education whereas only $13.6 \%$ have Western education in addition to Arabic education in humid rain forest of Imo State, Nigeria. Niamir (1990) reported that, even though formal schools provide literacy needed in modern times, their content remain too foreign to the pastoralists. This is because they teach the value of sitting in offices behind desks, rather than the value of the land. Adisa and Badmos (2009) also reported that, only $14 \%$ of herdsmen have formal education and about $64 \%$ of herdsmen interviewed in Kwara state have no education at all. This pathetically low level of Western education among pastoralists in the study areas is buttressed by the study of Aikman (2008) which revealed very low school enrollment rates and high drop-out rates among school-age pastoralists.

(e) Years of experience of cattle producers in Adamawa State 
Field observations and information gathered as shown in Table 1e also indicated that, majority of the cattle producers had acquired enough experience in the profession even though most of them did not receive any formal training on livestock production. Most of them (40.00 to $45.00 \%$ ) had experiences of 17 to 22 years in the industry and cattle production business has become part of their way of life. It was confirmed that, they could not do without livestock production because virtually all their lives revolve around livestock keeping, as many were born into it. The results also corroborate that of Okoli et al. (2012), who reported similar years of experience amongst the Fulani pastoralists herders in the humid rain forest of Imo State, Nigeria. They reported that, majority of the pastoralists in the study area have gained reasonable years of experience between 10 and 20 years in herding. In a similar study, Adisa and Badmos (2009) reported $80 \%$ of respondents to have herded cattle for at least 5 to 10 years.

Older Fulani herdsmen with above 20 years of experience may have relinquished the grazing duty to the younger generation. It was found that, without a specific retirement age, most Fulani continue herding till the middle age. When a pastoral Fulani man becomes old and incapable of performing the rigorous herding task, he relinquishes the responsibility to his children. He then settles in the camp and acts as the chief adviser on family and herding matters. His wealth of experience makes him the trainer of the emerging household heads. An important function of the elderly in the Fulani society is making decisions about grazing movement. Field observations revealed that, culinary responsibility falls on the women who process and cook food. Girls and women weave mats, spin cotton into thread, make household decorations, and collect herbs and vegetables. Women also buy food from the open market, milk the cows, churn the milk, make the butter, sell the milk and butter, and do craft work such as decorating calabashes. They also grow vegetables, and raise poultry and non-ruminant stock, clean the compound and look after the sick, old, disabled animals, fetch water, collect firewood, collect wild-food, help in making temporary tents, and bear and nurture the children.

(f) Tribal distribution of cattle producers in Adamawa State

The results in Table 1f, showed that, majority of the cattle holders in the three study areas were Fulani by tribe representing 95.00, 70.00 and $65.00 \%$ in Jada, Mubi North and Gombi Local Government Areas, respectively. A similar study conducted by Suleiman (1988) in the derived savannah of Oyo State, Nigeria revealed that, cattle production is generally associated with pastoral Fulani race who are said to own approximately $90 \%$ of the national herd. Another study conducted by Mohammed (1990), showed that, a sizeable population of agro-pastoralists in the hinterlands of the derived savannah of Oyo State of Western Nigeria were originally normadic cattle pastoralists. It was found that, the few Hausa and other tribes with cattle holdings in the study areas were mostly absentee farmers, who hire the services of Fulani herdsmen to take care of their animals, while they reside and work in the cities. This is because the Fulani man thinks herding of cattle is his birth right and nobody else should do it. Therefore, he would do everything within his reach to dispossess other tribes from their holdings if the herds are kept by Non-Fulani famers. In the fear of losing their stock to Fulani men, other tribes tend to play safe by acting at the background. Olafadehan and Adewumi (2010), in their study of livestock management and production systems of Agropastoralists in the derived savannah of SouthWest, Nigeria reported that, all the agropastoralists interviewed inherited their stock, while few $(24 \%)$ engaged in care-taking of the animals for others.

\section{(g) Religious distribution of cattle producers in Adamawa State}

Table $1 \mathrm{~g}$ revealed that, more than half of the cattle keepers in the study locations are Muslims as compared to Christians and 
traditionalists. Jada LGA recorded $80.00 \%$ muslim pastoralists followed by Mubi LGA with $75.00 \%$ and Gombi LGA with $50.00 \%$. Christianity and traditional religions are, therefore, not so popular amongst the cattle farmers in Jada and Mubi North LGAs. This finding butressed the high level of Nomadic/Arabic education found amongst the farmers. Most of these Muslims believe that, Christianity is Western and since missionaries are the people who brought christianity to Nigeria, they resent the practice of this western way of life. These findings agree with the report of Adisa and Badmos (2009) who stated that, all of the pastoralists investigated in Kwara State, were Muslims.

\section{Cattle Management Characteristics of} Pastoralists in Adamawa State

(a) Cattle breeds distribution in Adamawa

\section{State}

The results of breed characterization, herd size and purpose of production in the three study locations are presented in table 2a, respectively. The survey revealed that, White Fulani (Bunaji) was the most predominant breed $(50.00 \%)$ in Gombi LGA, while Red Bororo ( Rahaji) (53.00\%) and Adamawa Gudali $(50.00 \%)$ were the most predominant in Mubi North and Jada Local Government Areas, respectively. It was observed that, the White Fulani is the most popular and widely spread and accepted in the state, because of their multi - purpose characteristics such as good market value traits, good tolerance to a variety of harsh conditions, resistance to a host of diseases and parasites, easy fattening and good coat colour traits. However, Adamawa
Gudali although the second most popular breed is concentrated in Southern Senatorial Zone and some parts of the Central Senatorial Zone. The breed is said to be hardy and able to withstand hash conditions compared to Red Bororo and Sokoto Gudali breeds because of their small stature.

Red Bororo and Sokoto Gudali are moderately distributed all over the state. They are more predominantly in the hands of transhumants that are in constant movement within the state and even across the states and international borders. The present finding is supported by Akabwai (1993), who reported that, pastoralists keeping Red Bororo and Sokoto Gudali breeds are highly mobile and which may include crossborder movements as well as movement into other largely inaccessible areas. Olafadehan and Adewumi (2010) reported that, in SouthWestern Nigeria breed composition of cattle in the agro-pastoralists stock favoured the White Fulani (Bunaji) followed by N'Dama and Keteku, which is the breed least kept by the farmers. This, also, corroborates the reports of Waters-Bayer (1988), who noted that, agropastoralists have preference for White Fulani (Bunaji) cattle because of their reputation for higher milk production, faster growth rate, large body size and good temperament. Again, Iro (1994), lyayi et al. (2003) and Olanite et al. (2003) also stated that, the slow maturing Sokoto Gudali cow and the lyre-horned, White Fulani cattle are the mainstay of the pastoral Fulani holdings. White and Wickens (1976) disclosed that, the White Fulani, though less hardy, has higher milk and beef yield compared to Sokoto Gudali.

Table 2 Cattle Management Characteristics in Adamawa State

\begin{tabular}{lllllll}
\hline Parameters & \multicolumn{2}{c}{ Mubi North } & \multicolumn{2}{c}{ Gombi } & \multicolumn{2}{c}{ Jada } \\
& Freq & \% & Freq & \% & Freq & \% \\
\hline (a) Breed & & & & & & \\
White Fulani & 27 & 27 & 50 & 50 & 30 & 30 \\
Red Bororo & 53 & 53 & 30 & 30 & 10 & 10 \\
Sokoto Gudali & 15 & 15 & 10 & 10 & 10 & 10 \\
Adamawa G. & 5 & 5 & 10 & 10 & 50 & 50 \\
(b) Herd Size & & & & & & \\
\hline
\end{tabular}




\begin{tabular}{|c|c|c|c|c|c|c|}
\hline $20-30$ & 20 & 20 & 25 & 25 & 10 & 10 \\
\hline $31-40$ & 25 & 25 & 25 & 25 & 15 & 15 \\
\hline $41-50$ & 50 & 50 & 45 & 45 & 40 & 40 \\
\hline $\begin{array}{l}51 \text { and above } \\
\text { (c) Prod }\end{array}$ & 5 & 5 & 5 & 5 & 35 & 35 \\
\hline Purpose. & & & & & & \\
\hline Meat & - & - & - & - & - & - \\
\hline Milk & - & - & - & - & - & - \\
\hline Breeding & - & - & - & - & - & - \\
\hline Traction & - & - & - & - & - & - \\
\hline Multi - Purpose & 100 & 100 & 100 & 100 & 100 & 100 \\
\hline
\end{tabular}

(b) Cattle herd size distribution in Adamawa State

The results on herd size distribution showed that, majority of the cattle producers in all the three study locations, Mubi North (50.00\%), Gombi (45.00\%) and Jada (40.00\%) maintained herd size of 41 to 50 heads of cattle comprising both bulls, heifers and cows (Table 2b). The findings corroborate that of Okoli et al. (2012) who reported that, majority of Fulani pastoralist $(63.60 \%)$ maintained herd size of 41 to 70 heads in the humid rain forest of Imo State, Nigeria. In a related study, Adisa and Badmos (2009), reported an average cattle herd size of 41 , while majority of herdsmen $(46.4 \%)$ herded 41 - 60 cattle. Iro (1994), also, reported optimum Fulani cattle herd size to be $80-100$, while Cunnings (1966) found 100 - 150, which is far higher than what was obtained in the present study. The low herd sizes obtained in this study could be attributed to the effects of dwindling feed resources associated with shrinking land that forces the stake holders to maintain lower herd sizes to march the natural pastures and available biomass (Okoli et al., 2012).

(c) The production purposes of cattle producers in Adamawa State

The results of production purposes revealed that, all the pastoralists at the three locations reared cattle for multiple purposes, chiefly for breeding, milk and meat production and traction (Table 2c). There is, therefore, no specialty in the production systems. This may be because of lack of technical know- how and infrastructural facilities, meaning that, most of the cattle finally end up as beef. This, also, agrees with Okoli et al. (2012) who reported that, all Fulani pastoralist keep cattle for breeding and dual purpose (milk and meat production) in the rain forest zone of Imo state. However, according to Alphonsus et al. (2012), there is no tropical breed that can be seen as a specialized dairy or beef type, some breeds are preferred for milk production, while others for beef. They also reported that, many breeds are dual purpose or multi-purpose and fulfill a variety of roles as producers of milk, draught power, meat, dung and hides. The results of this study supported that of Corbet et al. (2005) and Anderson (2003) who reported that, cattle provide draught animal power, social and cultural functions as well as serving as security and risk reduction in rural households. Adisa and Badmos (2009) also reported that, all of the pastoralists cattle producers surveyed in Kwara State keep their cattle purely for income generation ranging from milk, draft, manure, beef to breeding purposes.

\section{Reproductive Practices of Cattle Producers in Adamawa State}

The results of breeding system, mating method, bull to cow ratio, age at first service, age at first calving and calving rate per cow before culling are presented in Table 3 . The reproductive performances of a herd have been shown to be one of the most important starting points in any animal production package (Mukasa-Mugerwa et al., 1992). Malau-Aduli et al. (1993) and Mukasa-Mugerwa et al. (1992), defined fertility as the ability of male and female animals to produce viable germ cells, mate, conceive and deliver normal living young ones. Thus, the lifetime productivity of a cow is influenced by 
age at puberty, age at first calving, calving interval and number of services per conception and calving to conception interval. Similarly, Oni et al. (1988) and Shehu et al. (2005) stated that, reproductive ability is the primary source of all benefits derived from livestock so that, any selective breeding should be tailored towards increasing animal production traits. Reproduction is, therefore, the most important factor in determining profitability in a cow-calf enterprise.

\section{(a) Breeding system}

The study showed that, all the farmers practiced uncontrolled breeding system, with animals being allowed to graze together and breed freely without restriction (Table $3 \mathrm{a}$ ). It was observed that, cows become pregnant throughout the year, thus, spreading the income from milk sales. These findings agree with Okoli et al. (2012) who reported that, in the humid rain forest zone of South-Eastern Nigeria, $77.30 \%$ of the Fulani pastoralists did not specifically control breeding rate in their flock, resulting in uncontrolled breeding, while only $22.70 \%$ of the respondents allow cross breeding. Similarly, Kubkomawa et al. (2011), in their study of trailing and preservation of local breeds of livestock in North-Eastern Nigeria, reported that, the practice of uncontrolled breeding and indiscriminate crossbreeding results to diminishing genetic resources in many tropical environments.

Under this practice, calves usually wean themselves when the dam ceases milking but pastoralists resort to artificial weaning when the dam is in an advanced stage of pregnancy and the previous calf is still suckling. This is done by smearing the dung of young calves on the dam's teats every day until the calf stops sucking. Non-breeding bulls are not castrated unless they are troublesome, and usually not until they are 2 or more years of age. Castration is performed by crude surgical method, or by stretching the scrotum on a stick and crushing the spermatic cords with a mallet.

Table 3 Reproduction Practices of Cattle Producers in Adamawa State

\begin{tabular}{|c|c|c|c|c|c|c|}
\hline \multirow[t]{2}{*}{ Parameters } & \multicolumn{2}{|c|}{ Mubi North } & \multicolumn{2}{|c|}{ Gombi } & \multicolumn{2}{|c|}{ Jada } \\
\hline & Freq & $\%$ & Freq & $\%$ & Freq & $\%$ \\
\hline \multicolumn{7}{|l|}{ (a) Breeding Syst. } \\
\hline Cross breeding & - & - & - & - & - & - \\
\hline In - breeding & - & - & - & - & - & - \\
\hline Up - grading & - & - & - & - & - & - \\
\hline \multicolumn{7}{|l|}{ (b) Mating Meth. } \\
\hline Hand mating & - & - & - & - & - & - \\
\hline Pasture mating & 100 & 100 & 100 & 100 & 100 & 100 \\
\hline \multicolumn{7}{|l|}{$\begin{array}{l}\text { (c) Bull to Cow } \\
\text { ratio }\end{array}$} \\
\hline $1: 10$ & 75 & 75 & 50 & 50 & 20 & 20 \\
\hline $1: 50$ & 25 & 25 & 40 & 40 & 40 & 40 \\
\hline $1: 100$ & - & - & 10 & 10 & 40 & 40 \\
\hline \multicolumn{7}{|l|}{$\begin{array}{l}\text { (d) Age at first } \\
\text { service }\end{array}$} \\
\hline \multicolumn{7}{|l|}{ Bull and Heifer } \\
\hline 2 - 3 years & 40 & 40 & 55 & 55 & 50 & 50 \\
\hline 4 - 5years & 60 & 60 & 45 & 45 & 50 & 50 \\
\hline \multicolumn{7}{|l|}{ (e) Age at first } \\
\hline \multicolumn{7}{|l|}{ Heifer } \\
\hline 3 - 5 years & 27 & 27 & 20 & 20 & 25 & 25 \\
\hline $5-7$ years & 73 & 73 & 80 & 80 & 75 & 75 \\
\hline (f) Calving/ cow & & & & & & \\
\hline
\end{tabular}




$\begin{array}{lllllll}\text { before culling } & & & & & & \\ 1-5 \text { years } & 74 & 74 & 70 & 70 & 60 & 60 \\ 6-11 \text { years } & 26 & 26 & 30 & 30 & 40 & 40 \\ \begin{array}{l}12-\text { above years } \\ \text { (g) Reproductive }\end{array} & 73 & 73 & 80 & 80 & 75 & 75 \\ \begin{array}{l}\text { Enhancement } \\ \text { Use of Ethno - Vet. }\end{array} & 65 & 65 & 60 & 60 & 55 & 55 \\ \begin{array}{l}\text { Practices } \\ \text { Veterinary Services }\end{array} & 35 & 35 & 40 & 40 & 40 & 40 \\ \text { Special Feeding } & - & - & - & - & 5 & 5\end{array}$

Key: LRS = Late Rainy Season, EDS = Early Dry Season, LDS = Late Dry Season, ERS = Early Rainy Season Sample Size : N = 100/ L. G. A.

\section{(b) Mating methods}

The mating methods result showed that, the respondents allowed free pasture mating in the three study locations (Table $3 \mathrm{~b}$ ) indicating that, no form of hand mating or artificial insemination is practiced by the pastoralists in the study areas. This could be as a result of the expensive nature of $\mathrm{Al}$ equipment and the technicalities involved since most of them have no western education and are not interested in specialization but to maintain and increase herd number through natural and cheapest possible methods. These findings also agree with Okoli et al. (2012), who reported that, all pastoralists in the rain forest zone of Imo State allow free pasture mating of their flocks implying again that, there is uncontrolled cross breeding. Babayemi et al. (2014) also reported that, pasture mating is common among the cattle rearers in West Africa.

\section{(c) Bull to cow ratio}

The bull to cow ratio results (Table $3 \mathrm{c}$ ) across cattle herds at the three study locations showed that, majority of them allowed sex ratio of $1: 10$, with Mubi North LGA having $75.00 \%$, Gombi (50.00\%) and Jada (20.00\%). For sex ratio of 1:50, Mubi North LGA had $25.00 \%$, Gombi $(40.00 \%)$ and Jada $(40.00 \%)$. This is considerate since the recommended sex ratio by established cattle ranches is 1 bull to service 50 cows per year under controlled breeding system through hand mating or artificial insemination (Babayemi et al., 2014).

However, in situations where breeding is not controlled, one bull may be over worked if it's to service 50 cows continually throughout the year. Again, having too many service bulls in a herd encourages fighting leading to injuries amongst the male animals. Under ideal management, bulls not used for service should be castrated and fattened for sale or used as a draught and transportation animal, especially during migration. However, maintaining higher number of female animals guarantees herd growth and sustainability.

These results agree with Okoli et al. (2012), who examined bull to cow ratio in some herds of cattle reared by Fulani pastoralists in the humid rain forest of Imo State, Nigeria and found a gender imbalance, with a preponderance of the female stock. In their study, the female species constituted 60 to $73 \%$ of each herd. The advantages of keeping more female variety in the herd are obvious for fast herd growth and a simulation of herd dynamics proves that, the rate of growth of the herd peaks when female cattle dominate. In another study, Iro (1994) reported a preponderance of female over male at ratio $4: 1$ and that, the Fulani pastoralists maintain a balanced functional species composition that is made up of beefers, milkers, breeders, carriers, and stock beautifiers.

\section{(d) Age at first mating for bull and heifers}

The age at first mating by bulls and heifers showed that, $60.00,50.00$ and $45.00 \%$ of farmers in Mubi North, Jada and Gombi Local Government Areas, respectively, allowed their cattle to mate and breed at ages between 4 and 5 years. Again, 55, 50 and $40 \%$ cattle 
producers in Gombi, Jada and Mubi North, respectively, confirmed that their cattle mate and breed between the ages of 2 and 3 years old (Table $3 d$ ). This disparity in breeding ages across the three study locations could be as a result of differences in herd composition, sex ratio and management systems, availability of forages and crop residues and health care delivery. For example, it was observed that, where there are more males in herd reproductive activities were more rampant with high incidence of early breeding. Availability of feed resources, space and health care also affect positively the animal's puberty age, thereby, creating room for early reproductive activity. Usually under good management practices cattle start sexual play and breed at 1 to 3 years old (Okoli et al., 2012). However, disease conditions, malnutrition, overcrowding and social vices could hamper early sexual maturity among cattle breeds of tropical origin.

\section{(e) Age at first calving for heifers}

It has been observed that, age at first calving is important in the entire reproductive life of a heifer and that, the earlier the heifer starts to deliver young ones the better economically for the producers. The results of this study as shown in table $3 e$ revealed that, majority of the herds had their heifers calved between the ages of 5 and 7 years, with Gombi LGA $(80.00 \%)$ having the highest cases followed by Jada LGA $(75.00 \%)$ and Mubi North LGA (73.00\%). Only few cases of calving at 3 to 5 years age of heifers were recorded at all the three study locations. It has been observed that, age at first calving of 3 to 7 years for tropical breeds of cattle is not too bad considering the production components of the tropical livestock industries especially, the limited resources available (Okoli et al., 2012).

\section{(f) Number of calving before culling}

Table $3 f$ showed that, majority of cows at the three study locations delivered an average of 5 to 12 calves before they were culled off, with Adamawa Gudali having higher reproductive performance followed by White Fulani breed. This is because Adamawa Gudali and White
Fulani breeds are indigenous to the study location and tend to adapt better to hard conditions of the environment more than the Red Bororo and Sokoto Gudali breeds that usually lose a lot of body condition and weights at critical periods of the year. The results agree with Okoli et al. (2012), who reported in their survey on animal reproductive management practices of Fulani pastoralists in the humid rain forest of Imo State, Nigeria that, $90.90 \%$ of the pastoralists allow $6-10$ calving per cow within its reproductive life, while a limited $9.10 \%$ may allow up to 11 - 15 calving per cow implying that, most of the female animals culled for sale are old animals. It was found that, majority of the cattle producers in the study area select and cull mostly sick, weak and old animals that have finished their productive activities. Healthy and reproductively active animals are rarely sold even when the farmers need cash to solve a pressing problem.

\section{(g) Reproductive enhancement of cows}

The findings in table $3 g$ revealed that, majority of the pastoralists in Mubi North LGA (65.00\%), Gombi LGA (60.00\%) and Jada LGA (55.00\%) used ethno -veterinary drugs to enhance the reproductive performance of their herds with only $35-40 \%$ of the farmers having access to conventional veterinary services. Only $5.00 \%$ of the famers, specifically at Jada LGA practised special feeding of animals to enhance their reproductive performance. These special feeds for the breeding stocks include salt licks, molasses and potash, which supply minerals and energy to the stock for optimal productivity. It was also found that, majority of farmers preferred ethno - veterinary approaches because it is readily available and cheap, while access to conventional veterinary health care is usually poor and exorbitant in rural Northern Nigeria.

Table 4 showed the common ethno veterinary medicines and ingredients in Adamawa State. It was observed that, twelve (12) different plant parts, such as roots, barks, leaves, flowers, juice or nectars, fruits, seeds, vegetable oils, castor oil, sugar, wood ash and charcoal are 
used in ethno - veterinary preparations. Fourteen (14) parts and products of animals, such as horns, skins and hides, bones, milk, butter, cod liver oil, fish oil, snake oil, old honey and even urine and dung also form the ingredients for ethno-veterinary preparations. Other ethno-veterinary ingredients include 6 earth materials such as edible earth, termite and anthills, magic black stones, limestone, salt and red potash, which are commonly used in decoctions and concoctions based on their healing and preservative properties.

Eight (8) spiritual forces may, also, be invoked by prayers during rituals. It was found that, rituals are important in the interaction between African livestock keepers and their animals. To ensure that the herd thrives and increases in size, animal husbandry is usually ritualized. Numerous rituals are performed, such as invoking the gods through dance or the sacrifice of an animal. Other rituals involve writing a phrase from the Koran on a slate and washing it in a calabash. The liquid is then used to drench the sick animal. Ritual incantations and prayers are sometimes connected with particular plants and special ingredients. Some protective charms are hung on the neck of animals to protect them from theft and calamities. Hot iron are used in branding and tattooing the animals for the treatment of ailments. It was observed that, the common plant parts used were bark of Acacia spp, fruit of Hibiscus esculentus and the leaves of Carica papaya. Also, whole Aloe vera and Ginger plants are used for high fever and the bark of dargaza (draw) plant is used to formulate a draw solution which is used to remove retained placenta in cattle and treatment of bloat. Bitter leaves, bark of acacia plant and its fruits, citrus plant and neem tree are used for the control of helminth and ecto- parasites in cattle. Ground nut and palm oil, salt and detergent solution are used for the treatment of constipation in calves and bloat treatment in adult, especially, when polythene bag is ingested.

McCorke (1986) reported that, ethno-veterinary medicine is a scientific term for traditional animal health care that encompasses the knowledge, skills, methods, practices, and beliefs about animal health care found among community members. Similarly, Misra and Kumar (2004) stated that, EVM is the community-based local or indigenous knowledge and methods of caring for, healing and managing livestock. This, also, includes social practices and the ways in which livestock are incorporated into farming systems. These findings support the report of Okoli et al. (2010) that, ethno-veterinary medicine in west Africa is usually made up of many components that may include ethno-botany, ethno-practice and magic among others.

Table 4 Ethno-Veterinary Medicine and Ingredients in Adamawa State

\begin{tabular}{ccccc}
\hline S/n & Plant parts & Animal parts & Earth material & Spiritual force \\
\hline 1 & Roots & Horns & Salt & Prayers \\
2 & Barks & Hides/skins & Edible earth & Dance \\
3 & Leaves & Bones & Termite/Anthills & Incantations \\
4 & Flowers & Milk & Magic stones & Rituals \\
5 & Juice/ Nectars & Butter & Limestone & Sacrifice \\
6 & Fruits & Cod liver oil & Red potash & Koran slate \\
7 & Seeds & Fish oil & & Charms \\
8 & vegetable oils & Snake oil & & \\
9 & Ash/Charcoal & Urine/ dung & & \\
10 & Castor oil & Spleen/liver & & \\
11 & Palm oil & Rumen & & $\mathbf{8}$ \\
12 & Sugar & Old honey & & \\
13 & & Feathers & & $\mathbf{6}$ \\
Total & $\mathbf{1 2}$ & Spines & & \\
\hline
\end{tabular}


(h) Seasonal calving rates of cattle in Adamawa State, Nigeria

Table 5 showed the seasonal calving rates of cattle in Adamawa State, Nigeria. High calving rates of $85.00,80.00$ and $75.00 \%$ were recorded in Mubi North, Gombi and Jada LGAs, respectively during the late rainy season (LRS), while $85.00,80.00$ and $55.00 \%$ were reported in Gombi, Jada and Mubi North LGAs, respectively, during the early dry (EDS). This was possible because of the availability of forages and crop residues during those periods, which coincide with high natural supply of nutrients to the animals and good atmospheric conditions for breeding and calving. Low calving rates were, however, recorded during the late dry (25.00 - 40.00\%) and early rainy $(5.00-15.00 \%)$ seasons which are critical natural resources are limiting periods of the year. These critical periods are usually characterized by lean feed resources of poor quality as well as high wind and dust borne diseases. During these periods, the pasture and range lands become defunct, forages are dried up and bush fire clears large proportion of pastures leaving only forages along river banks, crop residues and by - products as the only sources of feed for cattle to scavenge. As a result of this, animals are unable to meet their protein and energy needs from available lowquality herbage with consequent marked weight loss and productivity. For example, studies have shown that, the crude protein (CP) content of native grasses during the dry season is about 1.5 to $3 \%$ (Adamu et al., 1993) and is far below the minimum level of $7 \% \mathrm{CP}$ required in forages to enhance voluntary intake, digestibility and utilization by ruminants (Smith, 1993). Thus, the conservation and utilization of cheap and readily available feedstuff is a major challenge facing livestock farmers in Northern Nigeria amidst feed crisis (Bogoro, 1997). These cheap feed resources include crop residues, agro-industrial by-products, animal processing wastes, brewery waste and byproducts, farm animal wastes (poultry litters, animal faeces) and other forms of fibre, protein and energy by- products suitable for ruminant feeding as well as browse plants (Adegbola, 1985; Alhassan et al., 1987).

Table 5 Seasonal Calving Rates of Cattle in Adamawa State

\begin{tabular}{lllllll}
\hline \multicolumn{1}{c}{ Parameters } & \multicolumn{2}{c}{ Mubi North } & \multicolumn{2}{c}{ Gombi } & \multicolumn{2}{c}{ Jada } \\
& Freq & \% & Freq & \% & Freq & \% \\
LRS(July-Spt.) & & & & & & \\
High & 85 & 85 & 80 & 80 & 75 & 75 \\
Average & 10 & 10 & 15 & 15 & 20 & 20 \\
Low & 5 & 5 & 5 & 5 & 5 & 5 \\
EDS(Oct-Dec.) & & & & & & \\
High & 55 & 55 & 85 & 85 & 80 & 80 \\
Average & 41 & 41 & 10 & 10 & 15 & 15 \\
Low & 4 & 4 & 5 & 5 & 5 & 5 \\
LDS(Jan-Mar) & & & & & & \\
High & 25 & 25 & 30 & 30 & 40 & 40 \\
Average & 40 & 40 & 40 & 40 & 40 & 40 \\
Low & 35 & 35 & 30 & 30 & 20 & 20 \\
ERS(Apr-Jun) & & & & & & \\
High & 15 & 15 & 10 & 10 & 5 & 5 \\
Average & 25 & 25 & 20 & 20 & 25 & 25 \\
Low & 60 & 60 & 70 & 70 & 70 & 70 \\
\hline
\end{tabular}

Key: LRS = Late Rainy Season, EDS = Early Dry Season, LDS = Late Dry Season, ERS = Early Rainy Season Sample Size : N = 100/ L. G. A. predominated by experienced, married, male 
Fulani Muslims aged mostly $31-40$ years and having limited western education, indicating limited change in the socio-cultural status of actors in the face of a rapidly changing production environment exemplified specifically by shrinking land and vegetal resources.

The common cattle breeds encountered in the state were the indigenous Zebu cattle, with the White Fulani (Bunaji), predominating at Gombi LGA, the Red Bororo (Rahaji) at Mubi north, Adamawa Gudali at Jada LGA and Sokoto Gudali (Bokoloji) being sparingly distributed across the study area. Most predominant herd size was 40 to 50 cattle reared for multipurposes, indicating shrinking herd size in comparison with earlier reports of larger herd sizes (Cunnings, 1966) probably in response to shrinking pastoral land and vegetal recourses. Uncontrolled breeding, high levels of reproductive live wastage and high ethnoveterinary patronage against conventional veterinary services was evidenced, indicating

\section{REFERENCES}

Adamu, A. M., Eduvie, L. O., Ehoche, W. O., Lufadeju, E. A., Olorunju, S. A. S., Okaiyeto, P. O., Hena, S. W., Tanko, R. J., Adewuyi, A. A., \& Magaji, S. O. (1993). Effect of nitrogen, energy and mineral supplementation on the growth and reproductive performance of Bunaji heifers grazing native pastures and crop residues. In $A$. M. Adamu, R. I. Mani, O. A. Osinowo, K. B. Adeoye and E. O. Ajileye (Ed.) Proceedings of Workshop on Forage Production and Utilization in Nigeria, Second Livestock Development Project, NLPD, Kaduna, Nigeria, June 1993, pp. 166-176

Adebayo, AA (1999). Application of agro-climatology to agricultural planning in Adamawa State. Journal of Applied Science and Management, 1: 69 - 75.

Adebayo, AA and Tukur, AL (1991). Adamawa State In maps. Department of Geography, Federal

University of Technology, Yola Adamawa State. Paraclate publishing House, Yola, Nigeria, Pp. 27 87.

Adebayo, AA and Tukur, AL (1991). Adamawa State In maps. Department of Geography,

Federal

University of Technology, Yola Adamawa State. Paraclate publishing House, Yola, Nigeria, Pp. 27 87.

Adegbola, T.A. (1985). Browse plants: propagation management and utilization. in small ruminant production in nigeria. proceeding of the national conference on small limited adoption of modern animal production approaches by the pastoralists. Calving rates were particularly highly influenced by prevailing seasons with lowest rates during the early rainy season period.

The study therefore recommends that appropriate government agencies should formulate policies to address the static sociocultural conditions of pastoralists in Nigeria that resists adoption of agricultural technologies adapted to the realities of a modern world.

Governments should also address the major challenges of a changing pastoral environment characterized by shrinking land and vegetal resources due to expanding arable farm lands, construction, industrial and mining activities.

The Adamawa Gudali and to some extent the Red Bororo are recommended for further investigation as candidate cattle breeds that could be adopted for semi-sedentary production in the study area.

ruminant production, Zaria, Nigeria. 6 - 10 October, 1985, NAPRI, Shika Zaria. pp. 85-99.

Adisa, RS and Badmos AHA (2009). Socioeconomic correlates of perceptions of sustainability of pastoral livelihood among cattle herdsmen in Kwara state, Nigeria. Agrosearch, 10 (1and2): 21 - 30

Akabwai, DMO (1993). Paravet training among Turkana pastoralists of Kenya. In: Daniels P.W. (Ed) Livestock Services for Smallholders: A Critical Evaluation Proceedings of a Seminar held in Yogykarta, Indonesia. Indonesian International Animal Science Research and Development Foundation, Indonesia.

Alhassan, W. S. Kallah, M. S., \& Bello, S. A (1987). Influence of Duration of Stay on the Field on the Chemical Composition and Nutritive Value of Crop Residues. Tropical Agriculture (triandad), 64 (1), 61 - 64. Alphonsus, C, Akpa, GN, Barje, PP, Finangwai, HI, and Adamu, BD (2012). Comparative evaluation of linear udder and body conformation traits of bunaji and friesian $x$ bunaji cows. World Journal of Life Science and Medical Research, 2 (4):134 - 140.

Anderson, S. 2003. Animal genetic resources and sustainable livelihoods. Ecol. Econ. 45 (3): 331- 339.

Anosike, JC, Opara, MN, Okoli, CG, Kyakya, A and Okoli, IC (2003). Bovine trypasomiasis in sedentary cattle at the previously assumed trypanosoma- free, Jos Plateu, Nigeria. Nigerian Veterinary Journal, 24 (1): 3336. 
KUBKOMAWA et al., IJAR, 2017; 1:3

ASMLS 2010a. Adamawa State Ministry of Land and Survey. Map of Nigeria showing all states.

ASMLS 2010b. Adamawa State Ministry of Land and Survey. Map of Adamawa State of Nigeria showing all local government areas.

Babayemi, OJ, Abu, OA and Opakunbi, A (2014). Integrated animal husbandry for schools and colleges. First edition, published in Nigeria by positive press lbadan. Pp. 1 - 299.

Bassett, TJ and Turner, MD (2006). Sudden shift or migratory drift? Fulbe herd movements to the SudanoGuinea Region of West Africa. Human Ecology, 34: Online Edition (c) Springer Science+ Business Media, LLC 2006.

Blench, R (1994). The expansion and adaption of Fulbe pastoralism to subhumid and humid consitions in Nigeria. Cahiers d'etudes africaines 34 (133-135): $197-212$.

Blench, R (2010). Conflict between Pastoralists and cultivators in Nigeria, Kay Williamson educational foundation Cambridge, Pp. 29 - 105.

Bogoro, S. E. S. (1997). Effect of protein-energy supplementation on rumen kinetics, metabolite profile and growth performance of rams fed high fibre diets. Ph.D. Thesis, ATBU, Bauchi, Nigeria.

Bonfiglioli, AM (1992). Pastoralists at a Crossroads: Survival and Development Issues in African Pastoralism. Nomadic Pastoralists in Africa Project, UNICEF/UNSO, Nairobi, Kenya. Pp. 34 - 87.

CBN (1999). Central Bank of Nigeria annual report of 1998, Lagos Nigeria, 10: 41 - 80.

Cisse, S (1980). Sedentarization of nomadic pastoralists and pastoralization of cultivators in Mali. In: The future of pastoral people: Proceedings of a Conference Held in Nairobi, August $4-8,1980$, by the Institute of Development Studies. Nairobi: I. D. S., Pp.123 - 144.

Corbet, NJ, Shepherd, RK, Burrow, HM, Prayaga, KC, van der Westhuizen, J and Bosman, DJ (2005). Evaluation of Bonsmara and Belmont Red cattle breeds in South Africa. 2. Genetic parameters for growth and fertility. Austr. Journal of Exp. Agric. 46 (2): 213 - 223.

Cunnings, I (1966). Baggara Arabs. London: Oxford University Press, 31: 2045.

FAO (1996). Food and agricultural organization 1996. World development report paper no. 2, Rome Italy, Pp. 51-54.

Ifeanyi, AO and Olayode, GO (2008). Analysis of trends in livestock production in Nigeria from 1970-2005. Journal of Agriculture and Social Research (Jasr), 8 (1):114 - 120.

Ikede, BO and Taiwo, YO (1985). A survey of trypanosomiasis in the sedentary zebu and trypanotolerant cattle breeds in South -Western and North-Western Nigeria. Paper presented at the $18^{\text {th }}$ Meeting of ISCTRC, Harare, Zimbabwe. Pp. 122 -157. Iro, IS (1994). The fulani herding system, Washington, African development foundation. Pp. 6 -12. lyayi, EA, Okoruwa, VO, Babayemi, OJ and Peters, OF (2003). Livestock production pattern of agropastoralists in peri-urban centres of south-west Nigeria. Nigerian Journal of Animal Production, 30: 87- 92.

Johnson, DL (1993). Pastoral nomadism and the sustainable use of arid lands. Arid Lands Newsletter, 33: $26-34$.

Klein, JA, Harte, J and Zhao, XQ (2007). Experimental warming, not grazing, decreases rangeland quality on the Tibetan Plateau. Ecological Applications, 17:541-557.

Kubkomawa, HI, Helen, UO, Timon, F, Kabir, AM and Neils, SJ (2011). The use of camels, donkeys and oxen for post emergence weeding of farm lands in NorthEastern Nigeria. Journal of Agriculture and Social Sciences, JASS, 7 (4):136 - 138.

Malau-Aduli, AEO, Abubakar, BY and Dim, NT (1993). Studies of milk production and growth of Friesian $\mathrm{x}$ Bunaji crosses. II growth to yearling age, Journal of Animal Prod. Res., 13: 53 - 61.

Mbanasor, JA (2000). The future of livestock in Nigeria In: Ukachukwu, S.N., Ibeawuchi, J.A., Ibe, S.N, Ezekwe, A.G. and Abasiekong S.F. (Ed.). Animal production in the new millennium challenges and options, proceedings of the 25th animal conference held at the Michael Okpara University of Agriculture Umudike, Nigeria, March 2000, Pp. 8 - 16.

McCorke, C. M. (1986). An introduction to ethnoveterinary research and development. Journal of Ethnobiol., 6, 129-149.

Michael, W, Grindle, J, Nell, A and Bachman, M (1991). Dairy development in sub-Saharan Africa: A study of issues and options. Africa Technical Department Series No. 135. World Bank Technical Paper, Washington, DC. Pp. 27 - 209.

Misra, K. K., \& Kumar, K. A. (2004). Ethno-veterinary practices among the Konda Reddi of East Godavari district of Andhra Pradesh. Stud. Tribes Tribals, 2(1), 37 $-44$.

Mohammed, K (1999). Historical background, In Adebayo, A. A. and Tukur, A. L. (ed) Adamawa State in Maps, Paraclete Publishers, Yola. Pp. 39 -84.

Mohammed, TA (1990). A study of peri-urban cattle agropastoralism in the derived savanna of Oyo state, southwest, Nigeria. ILCA Humid.Zone Programme Research Report. Ibadan, Nigeria. Pp. 54.

Moran, EF (2006). People and Nature: An introduction to human ecological relations: Blackwell Publishing, Malden, MA., Pp. 52.

Moutari, M (2008). Securing Pastoralism in East and West Africa: Protecting and promoting livestock mobility Niger/Nigeria Desk Review. Pp. 78 - 98.

Muhammad, DN and Ardo, UA (2010). Enhancing livestock development and means of existence for the vulnerable populations through education and training: A case of nomadic education programme (Nep) in Nigeria animal husbandry and extension education services. 
national commission for nomadic education Kaduna, Nigeria. A paper presented at the CILSS,RPCA and OCDE forum on livestock breeding and food security held in Accra, Ghana. December, 14th - 16th December, 2010. Pp. 24 - 98.

Mukasa-Mugerwa, E, Tegegne, A and Ketema, H (1992). Patterns of postpartum Oestrus on set and associated plasma progesterone profile in Bos indicus cattle in Ethiopia. Journal of Animal Reprod. Sci. 24: 73 - 80.

Niamir, M (1990). Community forestry: Hunter's decisionmaking in natural resources management in arid and semi-arid Africa. Food and Agriculture Organization of the United Nations, Rome. Pp. 23 - 97.

Niamir, M (1991).Traditional African range management.Pastoral development network, OODI, London. Pp. 57 - 102.

Nori, M and Davies, J (2007). Change of Wind of Wind of Change? Climate Change, Adaptation and Pastoralism. Report prepared for the World Initiative for Sustainable Gunderson, L. H., and Holling, C. S. (2002). Panarchy: Understanding Transformations in Systems of Humans and Nature. Island Press, Washington, D.C. Pastoralism IUCN, Nairobi.

Nweze, BO, Ekwe, OO, Alaku, SO and Omeje, SI (2012). Productivity of two indigenous Nigerian cattle breeds and their crossbred under range grazing management. World Journal of Life Sci. and Medical Research, 2 (1): 1 - 8.

Nweze, BO, Otuma, MO, Ekwu, LG and Oga, G (2003). Agro Pastoral system in humid tropics. A case ofRice Muturu integrated farming practice in EbonyiState 8th Ann. Conf. Anim. Sci. Assocc. Nig. Sept. 17-19, 2003, Maiduguri Nigeria, Pp: 139 - 49.

Nyong, A (2010). Climate related conflicts in West Africa, In: Report from Africa population, heath, environment and conflict, ESCP report, 4 (12): 32 - 45.

Ofuoku, AU and Isife, BI (2009). Causes, effects and resolution of farmers-nomadic cattle herders conflict in Delta State, Nigeria. International Journal of Sociology and Anthropology, 1 (2): 047 - 054.

Okoli, IC and Kalla, DJU (2008). Regional response is key to mitigating the impact of environmental change on livestock production in West Africa. In: Food security and environmental change-linking science, development and policy for adaptation. An international conference, 2nd to 4th April, 2008. University of Oxford, UK.., No. 010.02 .

Okoli, IC, Enyinnia, NC, Elijah, AG, Omede, AA and Unamba-Opara Cl (2012).Animal reproductive management practices of Fulani pastoralists in the humid rain forest of Imo State, Nigeria. Journal of Animal Science Advances, 2: (2): 221- 225.

Olafadehan, OA and Adewumi, MK (2010). Livestock management and production system of Agropastoralists in the derived savanna of south-west. Nigeria Tropical and Subtropical Agroecosystems, 12: 685 - 691.
Olanite, JA, Busari, A and Akinlade, JA (2003). Performance of calves in the traditional Fulani agropastoral systems in the derived savanna of Oyo state, south-western Nigeria. Journal of Pure and Applied Science, 6: 203- 207.

Oni, OO, Buvanendaran, V and Dim, NI (1988). The Influence of some environmental factors on growth rate of two Nigerian cattle breed and their hybrid with Charolian. Journal of Animal Prod. Res., 8: 121- 131.

Parton, WJ, Morgan, JA, Wang, GM and Gross, SD (2007). Projected ecosystem impact of the prairie heating and $\mathrm{Co}_{2}$ enrichment experiment. New Phytology's, 174 :823 - 834.

RIM (1992). Nigerian national livestock resource survey (IV). Report by resource inventory and management limited (RIM) to FDL and PCS, Abuja, Nigeria, Pp. 231 456.

Roeleveld, WCA and van den Broek, A (1996). Focusing livestock systems research. Royal tropical institute, the Netherlands. Pp. 9 - 151.

Shehu, DM, Olurunju, SAS and Oni, OO (2005). Factors affecting the performances of Sokoto Gudali (biology) cattle from birth to yearling age, Journal of Tropical Biosci., 5: 81- 85.

Suleiman, H (1988). Policy issues on agropastoral development in Nigeria. Proceedings of National Conference on Pastoralism in Nigeria. Ahmadu Bello University, Zaria, Nigeria. Pp. 102 - 357.

Swinton, S (1987). Drought survival tactics of subsistence farmers in Niger. Human ecology, 1 (2): 108 $-122$.

Tibi, KN and Aphunu, A (2010). Analysis of the cattle market in Delta state - The supply determinants, African Journal of General Agriculture, 6 (4): 199 -203.

Tonah, S (2006). Managing farmer-herder conflicts in Ghana's Volta Basin. Ibadan Journal of Social Sciences, $4(1): 33-45$.

Tukur, HM and Maigandi, SA (1999). Studies on animal traction in North-eastern Nigeria. Characterization and management of animals used for draught. Tropical Journa of Animal Sci., 1(1): 10 - 27.

Umar, ASS (2007). Financial analysis of small scale beef fattening enterprise in bama local government area of Borno State. An unpublished M.sc. thesis, Ahamadu Bello University, Zaria, Nigeria. Pp. 25 - 72.

Umar, ASS, Alamu, JF and Adeniji, OB (2008). Economic analysis of small scale cow fattening enterprise in Bama Local Government Area of Borno State, Nigeria. Production Agricultural Technology, 4 (1): 1-10.

Walker, B and Salt, D (2006). Resilience thinking: Sustaining ecosystems and people in a changing world. Island Press, Washington, D. C., USA. Pp. 41 - 50.

Waters-Bayer, A (1988). Dairy by settled Fulani agropastoralists in central Nigeria. Farming System and Resources Economics in the Tropics. 4: 278. 
KUBKOMAWA et al., IJAR, 2017; 1:3

White, L and Wickens, G (1976). Land-use in the

Southern Margins of the Sahara In Management of Semi-

arid Ecosystem. Edited by B. Walker. Amsterdam:

Elsevier scientific publishing company, 26: 12 - 74. 